\title{
Tindakan Pemerintah Daerah Dalam Pengelolaan Hutan Kota Muhamad Sabki untuk Meningkatkan Sumber Pendapatan Daerah di Kota Jambi
}

\author{
Latifah Amir dan Ivan Fauzani Raharja \\ Email: latifaamir@rocketmail.com; ivanfauzani_fh@unja.ac.id
}

\begin{abstract}
ABSTRAK
Dengan disyahkannya UU No 23 Tahun 2014 tentang Pemerintah Daerah sebagai pengganti UU No 32 Tahun 2004 tentang Pemerintah Daerah semua ketentuan yang berlaku dalam UU No 32 Tahun 2004 tidak berlaku lagi dengan berlakunya UU No 23 Tahun 2014. Dalam Pasal 285 ayat (1) huruf a. Menyatakan bahwa salah satu sumber pendapatan daerah adaalah pendapatan daerah yang syah. Konsekwensi dalam pelaksanaan otonomi daerah bahwa setiap dari diberi kewenangan untuk mencari dan menggali potensi daerah yang bisa menjadi sumber pendapatan daerah baik Provinsi maupun Kota / Kabupaten. Di Kota Jambi salah satu aset daerah yang bisa mendukung sumber pendapatan daerah adalah Hutan Kota Muhamad Sabki tetapi anehnya kawasan hutan ini tidak dikelolala dan di tata dengan baik atau secara optimal oleh pemerintah Daerah Kota Jambi.Hasil dari penelitian dalam pengelolaan hutan Kota Muhammad Sabki yang pada saat ini sudah berubah status menjadi Taman Hutan Kota Muhammmad Sabki belum bisa dilakukan pengelolaaan secara optimal terkait dengan penggunaaan anggaran. Hasil yang dicapai dari retribusi Taman Hutan Kota Muhammad Sabki belum bisa untuk memenuhi kebutuhan dalam pengelolaannya.. Tipe penelitian ini adalah empiris dan bersifat deskripsi. Dari hasil penelitian ini bisa menjadi dasar bagi sipeneliti untuk penelitian selanjutnya. Dan dari hasil penelitian dapat memberikan masukan kepada pemerintah daerah penyebab tidak di kelololanya hutan kota secara optimal.
\end{abstract}

\section{Kata Kunci : Pengelolaan Hutan Kota}

\section{Latar Belakang Masalah}

\section{PENDAHULUAN}

Penyerahan sumber keuangan daerah baik berupa pajak daerah dan retribusi daerah maupun berupa dana perimbangan merupakan konsekwensi dari adanya peyerahan urusan pemerintah kepada daerah yang diselenggarakan berdasarkan azas otonomi. Untuk menjalankan urusan pemerintahan yang menjadi kewenangannnya, daerah harus mempunyai sumber keuangan agar daerah tersebut mampu memberikan pelayanan dan kesejahteraan kepada rakyat di daerahnya.

Otonomi daerah telah membawa berbagai perubahan mendasar dalam kehidupan bermasyarakat, sehingga peran, tugas dan fungsi lembaga-lembaga pemerinah daerah dituntut mencegah segala perubahan tersebut dan sehingga peran, tugas, fungsi lembaga itu seringkali belum dipahami dalam peraturan pemerintahan daerah satu kerja tim dengan yang satu sama lainnya saling mempengaruhi.

Sebagai konsep negara kesejahteraan dalam hal ini hukum administrasi menjadi bagian dalam kegiatan pemerintahan. Pengertian hukum administrasi negara bukanlah satu-satunya cara untuk menjelaskan konsep hukum administrasi negara, namun demikian sebagai pegangan pengertian hukum administrasi negara dapat dikemukakan dari beberapa pendapat para ahli, salah satunya J. Oppenheim yaitu hukum administrasi negara ialah keseluruhan 
aturan-aturan hukum yang harus diperhatikan alat perlengkapan negara dan pemerintah jika menjalankan kekuasaannya.

Menurut Juniarso \& Achmad Sodik Sudrajat Menyatakan :

"Kedudukan dan peran Pemerintah Daerah sangat strategis karena menjadi pondasi dari struktur pemerintahan di Indonesia dalam rangka mewujudkan kesejahteraan rakyat.

Penjelasan umum UU No 23 Tahun 2014 Tentang Pemerintah Daerah pengganti UU No 32 Tahun 2004, menyatakan, sebagaimana diamanatkan UUD 1945 terdapat urusan pemerintah yang sepenuhnya menjadi kewenangan urusan pemerintah pusat yang dikenal dengan urusan pemerintahan absolut dan ada urusan pemerintahan konkuren. Urusan pemerintahan yang konkuren yaitu urusan pemerintahan wajib dan urusan pemerintahan pilihan yang dibagi antara Pemerintah Pusat, Daerah provinsi dan daerah kabupaten/kota.

Sebagaimana diatur dalam Pasal 282 UUNo. 23 Tahun 2014 penyelenggaraan urusan pemerintahan yang menjadi kewenangan pemerintah daerah didanai dari dan atas beban Anggaran Pendapatan Belanja Daerah ( APBD). Konsekwensinya apa yang dimkasudkan oleh pasal 282 dalam peneyelenggaraan pemerintahan yang menjadi kewenangan daerah bahwa daerah harus mencari dan menggali apa yang menjadi sumber pendapatan daerah.

Sebagaimana yang sudah diatur dala Pasal 285 ayat (1) huruf a, sumber pendatan daerah terdiri atas:

Pendapatan asli daerah meliputi:

1. Pajak daerah

2. Retribusi daerah

3. Hasil pengelolaan kekayaan daerah yang dipisahkan

4. Lain-lain pendapatan asli daerah yang syah

Pasal 57 Undang-undang Nomor 32 Tahun 2009 tentang perlindungan dan Pengelolaan Lingkungan Hidup mengatur bahwa "pemeliharaan lingkungan hidup" adalah upaya yang dilakukan untuk menjaga pelestarian fungsi lingkungan hidup dan mencegah terjadinya penurunan atau kerusakan lingkungan hidup yang disebabkan oleh perbuatan manusia. Oleh karena itu ruang lingkup lingkungan termasuk juga salah satunya adalah pelestarian hutan.

Hutan merupakan hal yang penting dalam melestarikan lingkungan, karena fungsinya memperbaiki dan menjaga iklim mikro dan nilai estetika, meresapkan air, menciptakan keseimbangan dan keserasian lingkungan fisik kota dan mendukung pelestarian keanekaragaman hayati. Oleh karena itu hutan kota harus dilestarikan dan dipelihara dengan sebaik-baiknya oleh pejabat yang berwenang yang mengerti akan kondisi hutan kota.

Pasal 5 sampai Pasal 9 UU No 41 Tahun 1999 tentang Kehutanan, ditentukan 4 jenis hutan yaitu berdasarkan :

1. Statusnya diatur dalam Pasal 5

2. Berdasarkan Fungsinya diatur dalam Pasal 6

3. Berdasarkan tujuan khususnya diatur dalam Pasal 8

4. Berdasarkan pengaturan iklim mikro,estetika,dan resapan air disetiap kota ditetapkan kawasan tertentu sebagai hutan kota diatur dalam Pasal 9 .Pada dasarnya yang dimaksud dengan hutan adalah suatu kesatuan ekosistem berupa hamparan lahan yang berisi sumber 
daya alam hayati yang didominasi pepohonan dalam persekutuan alam lingkungannya yang satu dengan yang lainnya yang tidak dapat dipisahkan.

Diantara jenis hutan yang diatur dalam UU No 41 Tahun 1999 yang akan peneliti permasalahan adalah jenis hutan yang diatur dalam Pasal 9 yaitu pengaturan iklim mikro, estetika dan resapan air disetiap kota ditetapkan kawasan tertentu sebagi hutan kota. Jenis hutan yang dimaksudkan dalam Pasal 9 UU No 41 tahun 1999 ada di Kota Jambi yang diberi nama Hutan Muhamad Sabki. Hutan ini terletak di dalam Wilayah Kecamatan Kota Baru, kalau dilihat dari sisi geografisnya bahwa hutan ini merupakan paru-paru Kota Jambi yang berada dibawah penguasaan pemerintah daerah Kota Jambi. Kalau dilihat dari kasat mata bahwa hutan ini tidak dikelola dan ditata dengan rapi oleh pemerintah daerah Kota Jambi. Lingkungan hidup yang bersih dan sehat adalah hak asasi warga negara tapi yang terjadi pada kawasan-kawasan sumber daya alam hingga pesisir dan perkotaan bertolak belakang terjadi krisis warga akibat memburuknya kualitas hutan yang berkurang. Dengan demikian Pemerintah Kota Jambi membuat satu wadah rencana terhadap pengelolaan hutan dalam setiap gerak-gerik langkah pemerintah. koordinasi tetap menjamin peranan penting dalam merumuskan pembagian tugas, wewenang dan tanggung jawab dalam kesatuan organisasi atau instansi yang menekankan usaha manegerial untuk mencapai kontribusi yang diharapkan. Oleh karena itu untuk mencapai sasaran maka sebaiknya ada koordinasi yang baik antara instansi pemerintah itu sendiri maupun dengan unsur pemerintah terkait lainnya.

Dari hasil pengelolaan hutan ini akan berdampak positif terhadap sumber pendapatan daerah Kota Jambi, Menjadikan hutan kota Muhamad Sabki sebagai kawasan hutan wisata yang menyediakan sarana dan prasarana wisata yang mendukung terpelihara kawasan hutan. Pasal 285 UU No 23 Tahun 2014 tentang Pemerintah Daerah bahwa sumber pendapatan daerah salah satunya bersumber dari pendapatan daerah yang syah. Hal ini berarti daerah berupaya mencari sumber pendapatan asal berdasrkan peraturan perundang-undangan.

Dalam Peraturan Daerah Kota Jambi Nomor 06 Tahun 2009 Tentang Hutan Kota di Kota Jambi yang terdapat pada Pasal 18 yang berbunyi pengelolaan dan pemanfaatan, dan yang terdapat pada ayat 2 mengatakan bahwa pengelolaan hutan kota sebagaimana yang dimaksud meliputi tahapan kegiatan yaitu :

1. Penyusunan perencanaan pengelolaan;

2. Pemeliharaan;

3. Pemanfaatan;

4. Perlindungan dan pengamanan;

5. Pemantauan dan evaluasi;

Pengelolaan hutan merupakan hal menarik untuk diteliti lebih lanjut karena masih ditemui persoalan-persoalan yang dapat diangkat untuk dikaji. Apabila dilihat dari hasil pengamatan penulis dan fakta yang sebenarnya di lapangan dalam kaitannya dengan pengelolaan hutan kota tidak sejalan dengan apa yang diamanatkan dalam Peraturan Daerah Nomor 06 Tahun 2009 Tentang Hutan Kota di Kota Jambi.

Artinya bahwa hal ini tidak sesuai dengan prinsip-prinsip pengelolaan hutan kota yang tercantum dalam Pasal 18 ayat 2 huruf B yaitu pelaksanaan pemeliharaan hutan kota.

Berdasarkan uraian di atas peneliti sangat tertarik untuk mengkaji permasalahan ini Melihat arti penting dan dilandasi kemauan yang kuat untuk mengetahui lebih dalam 
mengenai tindakan pemerintah daerah Kota Jambi terhadap pengoptimalan hutan kota di Kota Jambi penulis tertarik untuk meneliti lebih lanjut yang dituangkan dalam karya ilmiah yang merupaka hasil penelitian dengan judul tentang: tindakan pemerintah daerah dalam pengelolaan hutan kota muhammad sabki sebagai salah satu sumber pendapatan daerah di kota jambi.

\section{Identifikasi Masalah}

Berdasarkan apa yang telah diuraikan pada latar belakang masalah, maka yang menjadi permasalahan dalam penelitian ini adalah:

1. Bagaimana tindakan pemerintah daerah terhadap pengelolaan Hutan Kota Muhammad Sabki di Kota Jambi?

2. Bagaimana koordinasi antara lembaga terkait dalam pengelolaan Hutan Kota Muhammad Sabki sebagai upaya meningkatkan pendapatan daerah di Kota Jambi.

\section{HASIL DAN PEMBAHASAN}

\section{Tindakan Pemerintah Daerah Kota Jambi Dalam Pengelolaaan Hutan Kota Muhammmad Sabki.}

\section{Profil Hutan Kota Muhammad Sabki}

Hutan Kota Muhammmad Sabki merupakan area rekreasi semua kalangan yang berorientasi untuk terwujudnya hutan kota menjadi pusat pelestarian keanekaragaman hayati yang mampu menciptakan iklim mikro dalam menjaga keseimbangan ekosistem dan menjadi pusat pendidikan berbasis lingkungan.

Hutan kota seluas 11 Ha diprakarsai oleh Drs. H. Muhammad Sabki (Alm) Walikota Jambi (1993-1997)ditetapkan berdasarkan Perda Kota Jambi Nomor 7 Tahun 2009 tentang Penetapan Hutan Kota, diresmikan 9 Juni 2010 oleh Walikota Jambi dr. H.R. Bambang Priyanto dengan penandatanganan prasasti "Taman Hutan Kota Muhammad Sabki" disaksikan Hj. Rosna Sabki.Pusat Pelestarian Keanekaragaman Hayati

Semula hutan kota berupa kebun karet tua, kemudian secara bertahap dilakukan rehabilitasi dan penanaman berbagai jenis tanaman langka dan koleksi hingga saat ini memiliki lebih 200 jenis tanaman. Terdapat beberapa jenis pohon yang telah tumbuh secara alami antara lain gaharu, sindur, pinang hutan rotan berbagai jenis dan durian hutan.

Pendidikan berbasis lingkungan di Taman Hutan Kota Muhammad Sabki antara lain penghijauan lingkungan, bina cinta lingkungan alam, pengolahan sampah organic, pertanian organic, percontohan peternakan, bidudaya tanaman hutan kayu dan bukan kayu, percontohan budidaya lebah, tumbuhan berkhasiat obat, pendidikan dan penelitian, pembibitan tanaman lindung dll.

Obyek Wisata Alam dan Wahana Outdoor Activity

Camping, meeting, training, arisan, reuni, rapat, musda, outbound, kegiatan pramuka, wisata pendidikan, rekreasi, lokasi shooting, lomba memancing, olah raga, MOS/ospek, lintas alam Kewenangan Dalam Pengelolaan Hutan Kota Muhammad Sabki Kota Jambi. 
Sebelum penulis membahas tentang proses pengelolaan hutan dalam bidang kehutanan, maka penulis terlebih dahulu memaparkan tentang kewenangan pemerintah dalam bidang kehutanan. Dalam kepustakaan hukum administrasi, wewenang selalu merupakan bagian penting dan menjadi bagian awal hukum Administrasi, karena objek administrasi adalah kewenangan pemerintah (bestuurs bevoegdheid). Dalam hukum Tata Negara, wewenang (bevoegdheid) dideskripsikan sebagai kekuasaan hukum (rechtmacht). Jadi dalam konsep hukum publik, wewenang berkaitan dengan kekuasaan.

Istilah wewenang sering dipertukarkan dengan istilah kewenangan. Namun demikian Prajudi Atmosudirdjo membedakan pengertian-pengertian kewenangan (autbority, gezagd) dan wewenang (competence, bevoegdheid). "Kewenangan (yang biasanya terdiri atas beberapa wewenang) adalah kekuasaan terhadap segolongan orang-orang tertentu atau kekuasaan terhadap sesuatu bidang pemerintahan (atau bidang urusan) tertentu yang bulat".

Kewenangan daerah di bidang kehutanan sebagaimana didasarkan pada pasal 66 Undangundang Nomor 41 Tahun 1999 tentang Kehutanan "Dalam rangka penyelenggaraan kehutanan, pemerintah menyerahkan sebagian kewenangan kepada pemerintah daerah pelaksanaan penyerahan sebagian kewenangan bertujuan untuk meningkatkan efektifitas pengurusan hutan dalam rangka pengembangan otonomi daerah".

Namun adapun dasar hukum yang mengatur pengurusan dalam pengelolaan hutan, adalah yang terdapat pada peraturan Daerah Kota Jambi Nomor 2 Tahun 2013 Tentang perubahan atas Peraturan daerah Kota Jambi Nomor 10 Tahun 2008 tentang pembentukkan organisasi dinas-dinas daerah Kota Jambi, yang dirubah dengan Peraturan Daerah No 14 Tahun 2016 tentang Pembentukan dan Susunan Perangkat Daerah Kota Jambi sebagaimana dijelaskan di dalam penjelasan pasal 2 adalah: Dengan peraturan daerah dibentuk perangkat daerah. Pasal 2 huruf d menyebutkan

Dinas daerah Kota Jambi mempunyai tugas membantu Walikota dalam melaksanakan urusan pemerintahan yang menjadi kewenangan daerah dan tugas pembantuan yang diberikan kepada Kota, dalam pengelolaan hutan kota menjadi kewenangan Dinas Dinas Lingkungan Hidup;

Dinas daerah dipimpin oleh seorang kepala dinas yang berada di bawah dan bertanggung jawab kepada walikota melalui sekertaris daerah. Dengan demikian peraturan Daerah Kota Jambi yang berlaku di tingkat daerah, selain itu perlu juga dilaksanakan usaha penerbitan dan pembinaan Aparatur Negara yang meliputi baik struktur, prosedur kerja, fasilitas dan sarana untuk menunjang Aparatur Negara yang bersih dan beriwibawa.

Untuk pengelolaan Hutan Kota Muhammmad Sabki sebagaimana yang diatur dalam Pasal 2 huruf h Peraturan Daerah No 14 Tahun 2016, bahwa salah satu tugas dari Dinas lingkungan Hidup adalah pengelolaan hutan dan pohon pelindung. Semenjak Januari 2017 pengelolaan Hutan Kota Muhammad Sabki berada dibawah kewenangan Dinas Lingkungan Hidup ( DLH) Tindakan Pemerintah Kota Jambi Dalam Pengelolaan Hutan Kota Muhammad Sabki.

Dalam hukum adminisitrasi bahawa tindakan pemerintah dalam meyelenggarakan pemerintahan terdiri dari dari 2 bentuk :

1. Perbuatan yang merupakan Perbuatan Hukum ( rechtshandelingen )

2. Perbuatan materil (feittellijkehandelingen)

\section{Tindakan Atau Perbuatan Pemerintah Yang Merupakan Perbuatan Hukum ( rechtshandelingen )}


Tindakan pemerintah atau perbuatan pemerintah yang merupakan perbuatan hukum adalah perbuatan yang menimbulkan akibat hukum. Akibat yang timbul baik untuk pemerintah maupun untuk masyarakat. Bentuk perbuatan hokum yang dilakukan oleh pemerintah daerah kota Jambi dalam pengelolaan Hutan Kota Muhammad Sabki dimana pemerintah daerah mengeluarkan beberapa peraturan perundang-undangan dalam bentuk peraturan daerah untuk menjaga eksistensi dan pengelolaan hutan Kota Muhammad Sabki. Peraturan tersebut antara lain :

1. Peraturan Daerah KotaJambi Nomor 06 Tahun 2009 Tentang Hutan Kota

2. Peraturan Daerah Kota Jambi Nomor 07 Tahun 2009 Tentang Penetapan Hutan Kota

3. Peraturan daerah Kota Jambi Nomor 12 Tahun 2009 Tentang Retribusi Taman Hutan Kota Muhammad Sabki

4. Peraturan Daerah Kota Jambi Nomor 3 Tahun 2013 Tentang Retribusi Jasa Usaha

5. Peraturan daerah Kota Jambi Nomor 9 Tahun 2015 Tentang Perubahan Atas Peraturan Daerah Nomor 3 Tahun 201 Tentang Retribusi Jasa Usaha.

Dalam pelaksanaan pengelolaan hutan. Seharusnya dalam pelaksanaan peraturan Daerah bahwa pemerintah daerah harus mengeluarkan peraturan wali Kota untuk pelaksanaan peraturan daerah, tapi dalam kenyataan bahwa pemerintah daerah kota jambi tidak ada mengeluarkan peraturan wali untuk pelaksanaan peraturan daerah. Dalam penyelenggaraan dalam pengelolaan hutan Kota Muhammmad Sabk bahwa pemerintah daerah hanya berpedoman kepada peraturan daerah.

\section{Tindakan Materil (feittellijkehandelingen ) Pemerintah Daerah Kota Jambi dalam Pengelolaan Hutan Kota Muhammad Sabki}

Tindakan nyata pemerintah daerah dalam pengelolaan hutan kota yaitu suatu tindakan nyata oleh pemerintah daerah bagaimana perbuatan atau tindakan yang dilakukan oleh pemerintah untuk mengoptimalkan pengelolaan hutan supaya bisa menjaga eksistensi hutan sesuai dengan fungsi hutan tersebut.

Menurut Khairul Fauzi, Kasi Pengelolaan Hutan Kota Dan Pohon Pelindung, bahwa dalam Pengelolaan hutan kota Muhammad Sabki baru diserahkan kepada Unit Pelaksana Tugas (UPT) Dinas Lingkungan Hidup pada bulan Januari tahun 2017 berdasarkan Peraturan Daerah Kota Jambi Nomor 14 Tahun 2016 tentang Pembentukan dan Susunan Perangkat Daerah sampai sat ini Peraturan Wali Kota sebagai petunjuk dalam pelaksanaan Peraturan daerah tersebut belum ada.

Pada saat ini pembenahan dalam pengelolaan Hutan Kota Muhammmad Sabki yang dilakukan oleh pemerintah daerah Kota Jambi yaitu :

a. Perubahan hutan yang berfungsi sebagai taman bermain bagi masyarakat Kota Jambi dengan memperbaiki sarana jalan dan lingkungan hutan.

b. Penataan taman dengan membuat sarang burung yang menjadi daya tarik pengunjung.

c. Menyediakan sarana pendidikan yang berbasis lingkungan

d. Menyediakan objek Wisata Alam dan Wahana Outdoor Activity, seperti camping, outbound, kegiatan pramuka,lokasi shouting, wisata pendidikan, lomba mincing dll.

e. Menyediakan pandopo untuk kegiatan meeting,arisan ,reuni, rapat dan musda.

Penataan ini terkait dengan penggunaan angggaran, karena sampai penelitian ini dilakukan bahwa konribusi retribusi untuk PAD Kota Jambi belum bisa mencapai target. Penerimaan 
retribusi yang da sekarang hanya cukup memenuhi penggunaan untuk peneglolaan kebersihan dan membayar penjaga hutan dan pegawai honor laiinnya. Dengan kondisi tersebut pemerintah daerah Kota jambi belum bisa berbuat banyak untuk memgfungsikan hutan secara optimal.

\section{Koordinasi Lembaga terkait dalam Pengelolaan Hutan Kota Muhammad Sabki untuk Meningkatkan Pendapatan Daerah Kota Jambi.}

Berdasarkan ketentuan yang diatur dalam Pasal 9 Peraturan Daerah nomor 06Tahun 2009 tentang Hutan Kota:

(1) Rencana pembangunan hutan kota disusun berdasrkan kajian dari aspek teknis,ekologis,social dan budaya setempat

(2) Penyusunan rencana pembangunan hutan kota sebagaimana sebagaimana dimaksud ayat (1) dilaksanakan oleh Dinas pertanian, Dinas Peternakan dan kehutanan dengan melibatkan instansi terkait.

Sebagaimana yang diatur dalam pasal tersebut dalam pengelolaan hutan kota bahwa dinas -dinas yang dimaksudkan dalam pasal 9 ayat (2) harus da coordinator dengan dinas tersebut tetapi dengan keluarnya Perda Kota jambi No 14 Tahun 2014 Tentang Pemebentukan dan Susunan Perangkat Daerah. Pengelolaan Hutan yang dulu berada dibawah pengelolaan Dinas kehutanan berdasakan Peraturan Daerah tersebut diserahkan kepada Dinas Lingkungan Hidup dibawah Kabid Ruang Terbuka Hijau.

Menurut Khairul Fauzi sampai saat ini pengelolaan Hutan Kota Muhammmad Sabki secara teknis dikelola oleh Dinas Lingkungan Hidup yang merupaka tugas dari Ruang Terbuka Hijau. Pada saat tertentu kalau ada acara baru minta bantuan pihak kepolisian untuk keamanan. Tetapi untuk kedepan dalam pengelolaan hutan secara optimal kemungkinan bias melibtkan dinas lain apabila sarana pertamanan sudah memadai.

Secara umum Anggaran Pendapat Belanja Daerah (APBD) merupakan objek utamanya untuk menjalankan suatu proses pelaksanaan dalam pengelolaan, pemeliharaan hutan, agar hutan terlihat lebih beroptimal, dan tetap terjaga ruang terbuka hijau di Kota Jambi.

Tetapi dalam hal ini masyarakat kurang berperan penting dalam pelaksanaan kerja sama terhadap pemerintah, sebabnya secara umum masyarakat belum mengetahui pentingnya hutan kota, dan manfaatnya hutan kota bagi lingkungan ditengah wilayah perkotaan."

Dari uraian pendapat diatas dapat diketahui kurangnya pengetahuan masyarakat terhadap Peraturan Daerah Nomor 06 Tahun 2009 Kota Jambi Tentang Hutan Kota yang dapat mempengaruhi jalannya pemeliharaan, pengelolaan, yang dilakukan masyarakat sekitar Hutan Kota Muhammad Sabki Kota Jambi. Masyarakat mempunyai tanggung jawab serta mewujudkan jalannya Peraturan Daerah yang sebagaimana mestinya.

\section{KESIMPULAN DAN SARAN}

\section{kesimpulan}

1. Tindakan yang dilakukan oleh pemerintah daerah Kota Jambi dalam pengelolaan Hutan Kota Muhammad Sabki yaitu berupa tindakan hokum yaitu tindakan yang menimbulkan akibat hokum yaitu dalam bentuk perbuatan mengeluarkan beberapa peraturan daerah 
untuk meningkatkan eksistensi hutan kota dan menjaga fungsi hutan. Sedangkan tindakan materil yaitu mengadakan penataan dan secara fisik sehingga hutan kota Muhammad Sabki menjadi taman bermain yang menarik bagi masyarakat Kota Jambi dan merupakan sa;ah satu icon tempat wisata di Kota Jjambi.

2. Dalam pengelolaan hutan Kota Muhammad Sabki sampai saat ini belum ada koordinasi dengan instansi lain atau UPT lain sehingga hutan tersebut hanya dikelola oleh Dinas Lingkungan Hidup Kota Jambi, yang merupaka tugas dari Bidang Ruang Terbuka Hijau . Hal in disebabkan untuk pengelolaan hutan ini belum ada peraturan wali kota untuk pelaksana teknis pengelolaannya untuk sementara dikelola sendiri leh Dinas Lingkungan Hidup Kota Jambi.

\section{saran}

1. Agar pengelolaan Hutan lebih optimal Sebaiknya dalam pengelolaan Hutan Kota Muhamad Sabki diserahkan kepada pihak swasta dan pemerintah daerah hanya cukup meyediakan lahan, semua sarana dalam pertamanan menjadi tanggungjawab pihak swasta dan pemerintah terima hasil bersih saja setiap tahun.

2. Pemerintah daerah secepat mengeluarkan peraturan wali kota sebagai pelaksana peraturan daerah untuk pengelolaan hutan kota.

\section{DAFTAR PUSTAKA}

Bagir.Manan, Menyongsong Pajar Otonomi Daerah, Pusat Studi Hukum Fakultas Hukum Universitas Islam Indonesia.Yogyakarta.2001

Bambang Pamulardi, Hukum Kehutanan \& Pembangunan Bidang Kehutanan, PT. Raja Grafindo Persada, Jakarta, 1999, hal. 235.

Juniarso Ridwan dan Achmad Sodik Sudrajat, Hukum Administrasi Negara dan Kebijakan Pelayanan Publik, Nuansa,Bandung, Cet I, 2010, hal 98

Romeijin, dikutip oleh SF. Marbun dan Moh. Mahfud MD, Pokok-pokok Hukum Administrasi Negara, ( Yogyakarta: Liberty; Cetakan pertama, 1987), hal 71.

Ridwan.HR Hukum Administrasi Negara.Rajawali Pers.Jakarta.2011

Salim, Dasar-Dasar Hukum Kehutanan. Jakarta.2008

Supriadi, Hukum Kehutanan dan Hukum Perkebunan di Indonesia,Jakarta. Sinar Grafika.2010

Sukamto Satoto, Pengaturan Eksistensi \& Fungsi Badan Kepegawaian Negara, Cet I, Penerbit CV. Hangar Kreator, Jogjakarta, 2004.

Sinambela, Lian Poltak, Reformasi Pelayanan Publik, Cet I, Penerbit PT. Bumi Aksara, Jakarta, 2006.

Sulaiman N. Sembiring. "Bahan Persentase Kebijakkan Dan Hukum Pengelolaan Sumber Daya Alam" Sumatera Barat 17 Mei 2002

Marzuki Mahmud. Metode Penelitian Hukum. Surabaya.2011

Utrecht. E Pengantar Hukum Administrasi Negara Indonesia,Fakultas Hukum

Dan Pengetahuan Masyarakat Universitas Padjadjaran..Bandung,1960. 